\title{
Universiteit
}

Leiden

The Netherlands

\section{Prothrombotic changes in users of combined oral contraceptives containing drospirenone and cyproterone acetate}

Vliet, H.A.A.M. van; Winkel, T.A.; Noort, I.; Rosing, J.; Rosendaal, F.R.

\section{Citation}

Vliet, H. A. A. M. van, Winkel, T. A., Noort, I., Rosing, J., \& Rosendaal, F. R. (2004). Prothrombotic changes in users of combined oral contraceptives containing drospirenone and cyproterone acetate. Journal Of Thrombosis And Haemostasis, 2(11), 2060-2062. Retrieved from https://hdl.handle.net/1887/5074

Version: $\quad$ Not Applicable (or Unknown)

License:

Downloaded from: https://hdl.handle.net/1887/5074

Note: To cite this publication please use the final published version (if applicable). 
develop thromboembolic complications [8] and/or recurrent miscarriages [10].

One other woman with FXII deficiency had a very low PAI-1 (plasminogen activator inhibitor) level and her OHP was below the mean for the control group. This may indicate that the OHP test could be a useful diagnostic tool for global assessments of overall thrombotic or hemorrhagic risk in individuals with combined genetic defects.

Although the number of subjects is relatively small, we believe that these results are promising and may indicate that determination of OHP could be a method of choice for recognizing prothrombotic conditions associated with FXII deficiency and for distinguishing individuals with similarly low FXII levels. It seems that this assay (rather than the simple FXII concentration) could be used as a predictor of possible thrombotic risk.

\section{References}

1 Tans J, Rosing J. Structural and functional characterisation of factor XII. Semin Thromb Haemost 1987; 13: 1-14.

2 Wachtfogel YT, DeLa Cadena RA, Colman RW. Structural biology, cellular intereactions and pathophysiology of the contact system. Thromb Res 1993; 72: 1-21.

3 Mannhalter C, Fischer M, Hopmeier P, Deutsch E. Factor XII activity and antigen concentration in patients suffering from recurrent thrombosis. Fibrinolysis 1987; 1: 259-63.

4 Kluft C, Dooijewaard G, Emeis JJ. Role of the contact system in fibrinolysis. Semin Thromb Haemost 1987; 13: 50-68.

5 Lammle B, Wuillemin WA, Huber I, Krauskopf M, Zurcher C, Pflugshaupt R, Furlan M. Thromboembolism and bleeding tendency in congenital factor XII deficiency - a study on 74 subjects from 14 Swiss families. Thromb Haemost 1991; 65: 117-21.

6 Dyerberg J, Stoffersen E. Recurrent thrombosis in a patient with factor XII deficiency. Acta Haematol 1980; 63: 278-82.

7 Koster T, Rosendaal FR, Brute E, Vandenbroucke JP. John Hageman's factor and deep-vein thrombosis: Leiden Thrombophilia Study. Br J Haematol 1994; 87: 422-4.

8 Zeerleder S, Schloesser M, Redondo M, Wuillemin WA, Engel W, Furlan M, Lammle B. Re-evaluation of the incidence of thromboembolic complications in congenital factor XII deficiency - a study on 73 subjects from 14 Swiss families. Thromb Haemost 1999; 82: 1240-6.

9 Braulke I, Pruggmayer M, Melloh P, Hinney B, Kostering H, Gunther E. Factor XII (Hageman) deficiency in women with habitual abortion: new subpopulation of recurrent aborters? Fertil Steril 1993; 59: 98 101.

10 Ogasawara MS, Aoki K, Katano K, Ozaki Y, Suzumori K. Factor XII but not protein $\mathrm{C}$, protein $\mathrm{S}$, antithrombin III, or factor XIII is a predictor of recurrent miscarriage. Fertil Steril 2001; 75: 916-9.

11 Zeerleder SA, Asmis L, Redondo M, Sulzer I, Lammie B. A patient with isolated prolongation of aPTT without hemorrhagic diathesis anamnesis: severe, hereditary factor XII deficiency. Ther Umsch 1999; 56: $509-12$.

$12 \mathrm{He}$ S, Antovic A, Blombäck M. A simple and rapid laboratory method for determination of haemostasis potential in plasma II. Modifications for use in routine laboratories and research work. Thromb Res 2001; 103: $355-61$.

13 Antovic JP, Antovic A. Does recombinant factor VIIa apart from overall hemostasis regulate TAFI dependent fibrinolysis - in vitro analysis using overall hemostasis potential (OHP) assay. Thromb Haemost 2003; 90: 620-8.

14 Levi M, Hack CE, de Boer JP, Brandjes DP, Buller HR, ten Cate JW. Reduction of contact activation related fibrinolytic activity in factor XII deficient patients. Further evidence for the role of contact system in fibrinolysis in vivo. J Clin Invest 1991; 88: 1155-60.

\title{
Prothrombotic changes in users of combined oral contraceptives containing drospirenone and cyproterone acetate
}

\author{
H. A. A. M. VAN VLIET, * T. A. WINKEL, * I. NOORT, ${ }^{*}$ J. ROSING $\dagger$ and F. R. ROSENDAAL $\ddagger$ \\ *Leiden University Medical Center, Department of Gynecology and Reproductive Medicine, Leiden; †Maastricht University, Cardiovascular \\ Research Institute Maastricht, Department of Biochemistry, Maastricht; and $¥$ Leiden University Medical Center, Department of Hematology and \\ Clinical Epidemiology, Leiden, the Netherlands
}

To cite this article: Van Vliet HAAM, Winkel TA, Noort I, Rosing J, Rosendaal FR. Prothrombotic changes in users of combined oral contraceptives containing drospirenone and cyproterone acetate. J Thromb Haemost 2004; 2: 2060-2.

Correspondence: H.A.A.M. van Vliet, Leiden University Medical Center, Department of Gynecology and Reproductive Medicine, PO Box 9600, 2300 RC Leiden, the Netherlands.

Tel.: +31 71 5264065; fax: +31 71 5248181; e-mail: h.a.a.m.van_vliet@, lumc.nl

Received 1 July 2004, accepted 6 July 2004
Oral contraceptives (OC) increase the risk of venous thrombosis through changes in procoagulant, anticoagulant and fibrinolytic parameters [1]. Thrombin generation-based activated protein $\mathrm{C}$ (APC) sensitivity is a global test for the net prothrombotic effect and predicts the risk of venous thrombosis $[2,3]$.

Recently, concern has been raised about the thrombotic risk of a new OC composed of $3 \mathrm{mg}$ drospirenone (DRSP) and 
$30 \mu \mathrm{g}$ ethinylestradiol $\left(\right.$ Yasmin $^{\circledR}$, Schering AG, Berlin, Germany) [4]. Also, a recent study showed a four-fold increased risk of thrombosis for users of OC containing cyproterone acetate (CPA) compared with users of OC containing levonorgestrel (LNG) and an 18-fold increased risk compared with non-users $[5,6]$.

It is desirable to predict the prothrombotic effect of new OC prior to the occurrence of many cases of thrombosis. Therefore, we compared the sensitivity to APC in users of drospirenonecontaining $\mathrm{OC}$ with that in users of other OC, some of which are known to increase the risk of thrombosis (e.g. desogestrelor cyproterone acetate-OC).

Healthy women using the same type of OC for at least four cycles were recruited by advertising in local newspapers, public and university buildings, student houses and general practitioner waiting rooms. Exclusion criteria were age $(<18$ years) and contraindications for OC use as stated by the World Health Organization. Blood samples were drawn between days 18 and 21 of the menstrual cycle. After the blood draw DRSPor CPA-containing OC users were requested to switch to a second-generation OC: $150 \mu \mathrm{g} \mathrm{LNG}$ and $30 \mu \mathrm{g}$ ethinylestradiol (Microgynon- $30^{\circledR}$, Schering AG) and second- or third-generation OC users were asked to switch to the DRSP-containing OC. A second blood draw was performed between days 18 and 21 of the fourth cycle after the change of OC type. The Medical Ethics Committee of the Leiden University Medical Center approved the study. All volunteers gave written informed consent.

Normalized APC sensitivity ratios (nAPCsr) were determined by quantifying the effect of APC on thrombin generation (ETP-based APC-resistance test) as described previously [2]. The APC-resistance test was performed in duplicate and without knowledge of the OC used or any other participant's characteristics. The samples were analyzed in random order in one series.

Between July and November 2002, 158 women aged 18-51 years were recruited. We excluded two women, one because of a history of diabetes mellitus and one because of a history of thrombosis. Forty-six women switched OC type of whom 40 returned for a second blood draw. One participant using a CPA pill was erroneously prescribed the DRSP pill instead of a LNG-containing OC. Five women in the group of switchers discontinued due to breast tenderness, increase in acne and hirsutism, pregnancy wish, a previously unreported history of high blood pressure or surgery. One woman was lost to follow-up. The various groups of OC users did not differ with respect to age and body mass index.

Users of OC containing DRSP or CPA had higher nAPCsr than users of LNG-containing OC, respectively, 4.1 and 4.0 vs. 3.0 (Table 1). Similar results were found for users of desogestrel (DSG)- or gestodene (GTD)-containing OC. In the 39 women who changed pills, the nAPCsr altered correspondingly, i.e. it increased when switching from LNG-OC to DRSP-OC and decreased when switching from DRSP- or CPA-OC to LNGOC (Table 1). Exclusion of participants with the factor $\mathrm{V}$ Leiden mutation $(n=14)$ or the prothrombin 20210 A mutation $(n=5)$ did not materially change the mean nAPCsr: DRSP-OC (3.7), CPA-OC (4.0), DSG-OC (3.9), GTD-OC (3.4) and remained all markedly higher than in users of LNGOC (2.8).

In this study of prothrombotic effects among 156 healthy users of various types of OC formulations, users of DRSPand CPA-containing $\mathrm{OC}$ were found more resistant to the anticoagulant action of APC than users of LNG-containing OC. In addition, we confirmed previous results on prothrombotic effects of third-generation progestogen-containing OC (DSG, GTD) [2]. The observations were not the result of differences between women rather than between OC, as proved by the results in women who switched OC. The prothrombotic effect of DRSP- and CPA-containing OC, as measured by APC-sensitivity, was similar to the effect of OC containing the third-generation progestogens DSG and GTD, which have a two-fold higher risk of thrombosis compared with LNGcontaining OC [1].

Our results confirm that the thrombin generation-based APC-resistance test discriminates between $\mathrm{OC}$ with a high risk of thrombosis (CPA, DSG and GTD) and OC with a lower thrombotic risk (LNG) [3]. It is therefore an excellent test to predict the thrombotic safety of OC before women experience an actual thrombosis. In our study, DRSP-containing OC users were less sensitive to APC than LNG-containing OC users, which predicts an increased risk of thrombosis. Therefore, even in the absence of clinical outcome data, we advise not

Table 1 Mean ETP-based nAPCsr in women using oral contraceptives containing different kind of progestogens

\begin{tabular}{|c|c|c|c|c|c|c|c|c|c|}
\hline \multirow[b]{2}{*}{ Progestogen type } & \multirow[b]{2}{*}{$N$} & \multirow[b]{2}{*}{ nAPCsr } & \multirow[b]{2}{*}{$95 \% \mathrm{CI}$} & \multirow{2}{*}{$\frac{\text { Progestogen type }}{\text { Switch to }}$} & \multirow[b]{2}{*}{$N$} & \multicolumn{2}{|c|}{ nAPCsr } & \multirow[b]{2}{*}{ Difference } & \multirow[b]{2}{*}{$95 \% \mathrm{CI}$} \\
\hline & & & & & & Before & After & & \\
\hline Levonorgestrel & 60 & 2.99 & $2.71-3.27$ & Drospirenone & 14 & 3.13 & 3.60 & +0.46 & $0.16-0.76$ \\
\hline Drospirenone & 23 & 4.13 & $3.53-4.74$ & Levonorgestrel & 5 & 3.55 & 2.73 & -0.83 & $-1.80-0.15$ \\
\hline Cyproterone acetate & 22 & 4.00 & $3.74-4.26$ & Levonorgestrel & 6 & 3.96 & 3.01 & -0.96 & -1.66 to -0.26 \\
\hline Desogestrel & 33 & 4.07 & $3.71-4.43$ & Drospirenone & 8 & 3.78 & 3.97 & +0.19 & $-0.11-0.49$ \\
\hline Gestodene & 12 & 3.66 & $3.04-4.29$ & Drospirenone & 3 & 2.78 & 2.79 & +0.01 & $-2.45-2.47$ \\
\hline Norgestimate & 4 & 5.24 & $3.13-7.36$ & Drospirenone & 2 & 4.61 & 4.93 & +0.31 & $-0.99-1.62$ \\
\hline Norethindrone & 2 & 3.62 & $2.15-5.08$ & Drospirenone & 1 & 3.73 & 2.36 & -1.38 & - \\
\hline
\end{tabular}


to prescribe DRSP-containing combined OC as a first choice for women starting OC.

\section{Acknowledgements}

We gratefully acknowledge Frans M Helmerhorst who initiated the project. We are indebted to Thea $\mathrm{C}$ VisserOppelaar, M Christella LGD Thomassen and Elke JP Magdeleyns for performing the laboratory tests and to Ank $\mathbf{J}$ Schreijer and Ingeborg de Jonge for data management. We gratefully thank all women who participated in the study.

Funding was from Leiden University Medical Center and Cardiovascular Research Institute Maastricht.

\section{Conflict of interests}

Jan Rosing: the laboratory of Jan Rosing acts as a reference laboratory for the ETP-based APC-resistance test in a study conducted by Schering AG.

\section{References}

1 Vandenbroucke JP, Rosing J, Bloemenkamp KW, Middeldorp S, Helmerhorst FM, Bouma BN, Rosendaal FR. Oral contraceptives and the risk of venous thrombosis. N Engl J Med 2001; 344: 152735.

2 Rosing J, Middeldorp S, Curvers J, Thomassen MCLG, Nicolaes GA, Meijers JC, Bouma BN, Buller HR, Prins MH, Tans G. Low-dose oral contraceptives and acquired resistance to activated protein $\mathrm{C}$ : a randomised cross-over study. Lancet 1999; 354: 2036-40.

3 Tans G, van Hylckama Vlieg A, Thomassen MC, Curvers J, Bertina RM, Rosing J, Rosendaal FR. Activated protein C: resistance determined with a thrombin generation-based test predicts for venous thrombosis in men and women. Br J Haematol 2003; 122: 465-70.

4 van Grootheest K, Vrieling T. Thromboembolism associated with the new contraceptive Yasmin. BMJ 2003; 326: 257.

5 Vasilakis-Scaramozza C, Jick H. Risk of venous thromboembolism with cyproterone or levonorgestrel contraceptives. Lancet 2001; 358: $1427-9$.

6 van Hylckama Vlieg A. Causes of Venous Thrombosis: Procoagulant Factors and Oral Contraceptives, Dissertation. Leiden: Leiden University, 2003.

\title{
Thalidomide, deep venous thrombosis and vasculitis
}

\author{
M. SILINGARDI, M. IOTTI, C. TRENTI, C. SALVARANI and I. IORI \\ Dipartimento Area Medical, Az. Ospedaliera S. Maria Nuova, Reggio Emilia, Italy
}

To cite this article: Silingardi M, lotti M, Trenti C, Salvarani C, lori I. Thalidomide, deep venous thrombosis and vasculitis. J Thromb Haemost 2004; 2: 2062-3.

See also Rus C, Bazzan M, Palumbo A, Bringhen S, Boccadoro M. Thalidomide in front line treatment in multiple myeloma: serious risk of venous thromboembolism and evidence for thrombophrophylaxis. This issue, pp 2063-5.

Thalidomide has been employed in recent years for its antiinflammatory and antiangiogenic properties in the treatment of several conditions including leprosy, systemic lupus erythematosus (SLE), Behcet's disease (BD) and solid and hematological malignancies [1,2].

An increased incidence of deep venous thrombosis (DVT) has been observed in malignancies, especially in multiple myeloma, during treatment with thalidomide combined with chemotherapy. Pathogenetic mechanisms of thalidomide associated DVT have not been clearly assessed. A possible role for acquired APC-R, increased levels of factor VIII coagulant activity, von Willebrand factor antigen and vascular endothel-

Correspondence: Mauro Silingardi, U.O. Medicina Interna, Centro Emostasi e Trombosi, Az. Ospedaliera S. Maria Nuova, Viale Risorgimento,80, 42100, Reggio Emilia, Italy.

Tel.: + 39 0522296533; fax: + 39 0522296853; e-mail: silingardi. mauro@asmn.re.it

Received 6 May 2004, accepted 25 June 2004 ial growth factor has been suggested. The role of thrombophilia is unclear $[3,4]$.

We describe a case of proximal DVT in a patient with SLE treated with thalidomide for cutaneous vasculitis.

A 65-year-old female satisfied the American College of Rheumatology criteria for SLE. Recurrent cutaneous vasculitis had been observed during a period of 5 years. Her medical history was remarkable for obesity, varicose veins and venous thromboembolism, having suffered of recurrent idiopathic superficial thrombophlebitis of lower limbs in the last 2 years. She had been treated with corticosteroids for 3 years.

In an attempt to spare corticosteroids, thalidomide (100 mg) was added. Fifteen days later the patient presented right lower limb swelling, pain and discomfort. No chest pain, dyspnea or hemoptysis was reported. Venous ultrasonography of the lower limbs was diagnostic for proximal DVT (right superficial femoral/popliteal vein) associated with recurrence of superficial thrombophlebitis (great saphenous vein). A perfusional lung scintigraphy was negative for signs of pulmonary embolism. The search for antiphospholipid antibodies (lupus anticoagulant, anticardiolipin antibodies, antibeta2-GPI antibodies), FV 